\title{
Review
}

\section{Perspectives on the Capabilities for the Selection of Strategic Projects}

\author{
Khalifa Mohammed Al-Sobai, Shaligram Pokharel * ${ }^{\mathbb{C}}$ and Galal M. Abdella \\ Department of Mechanical and Industrial Engineering, Qatar University, P.O. Box 2713 Doha, Qatar; \\ K.AlSobai@outlook.com (K.M.A.-S.); gmg5005@qu.edu.qa (G.M.A.) \\ * Correspondence: shaligram@qu.edu.qa
}

Received: 6 August 2020; Accepted: 25 September 2020; Published: 4 October 2020

check for updates

\begin{abstract}
Strategic projects are large scale, complex, and require significant investments and resources. These projects aim at gaining long-term social and economic benefits. Therefore, organizations focusing on strategic projects should use a consistent approach that suits their strategy, capability, and long-term expectations. Based on the four research questions and content analysis of the literature, generic processes used for the strategic project selection in tandem with the managerial capabilities are identified in this paper. The generic processes and managerial capabilities are used to develop a generic framework for strategic project selection. The framework is used for literature analysis in the paper. The review shows that both qualitative and quantitative methods are used for strategic project selection. Some possible research directions have also been proposed at the end of the review. The paper provides value to both researchers and practitioners in terms of tools available and a guidance on project selection through a structured process framework.
\end{abstract}

Keywords: strategic projects; process framework; decision making; project selection

\section{Introduction}

Strategic projects can be categorized based on time, investments, sustainability, or long-term business or social values. These projects require significant investments and resources; therefore, their alignment with the long-term organizational capability [1] and sustainability becomes very important. Therefore, strategic projects are prioritized for immediate take-up or holding, or cancellation [2].

Regardless of whether projects are deployed using portfolio management or program management, their prioritization becomes challenging [3], especially in the public sector. In public-sector strategic projects, national priorities over the long-term become necessary [4]; therefore, project selection should also focus on operational sustainability. On the other hand, strategic project selection in the private sector should focus on survivability and capability improvements [5]. Such private sector projects can be for a new product line or a change in the business model [6].

The strategic project selection requires the analysis of projects in different steps. Authors have provided different selection frameworks, but they are usually specific to a given project situation or project type. Further, project selection is also subject to changes in the business environment and the associated risk. Therefore, resulting projects may have problems in project coordination and management [5]. In addition, the selection process should also consider organizational managerial capabilities such as resource management [7], value management [8], governance [9], risk management $([10,11])$, and stakeholder management ([12-14]). These managerial capabilities support resource optimization and competitive value generation [15] to achieve organizational goals [16]. Good governance management promotes organizational mechanisms to ensure organizational growth [17]. The current research focuses on selection methods, but it is not explicit about the 
dynamic situation for a project selection cycle. Also, the importance of managerial capabilities has often been not considered explicitly. Naaranoja et al. [18] mention that an organization's managerial capabilities can support project sustenance. Therefore, this paper aims to fill the gap to develop a generic framework that considers the selection steps and managerial capabilities.

The lack of a generic strategic project selection framework drives the motivation for this review. The motivation is also driven by a lack of explicit consideration for the managerial capabilities of the organizations. These motivating factors lead to three research questions for review.

RQ1: What are the key steps for strategic project selection, and how are they applied to develop a list of projects for implementation?

RQ2: Which managerial capabilities are critical, and what should be considered in each capability?

RQ3: How do the critical managerial capabilities relate to the theory and practice of strategic projects' selection?

RQ4: What are the related future research directions for an effective strategic project selection?

The answers to the above questions are obtained through the content analysis methodology. The methodology used in this paper is consistent with those developed by ([19-22]) to explore, categorize, develop a framework for holistic understanding, and complete a literature analysis for each part of the framework. Other research using this type of method is also given in [19]. The proposed framework is generic; therefore, it is expected that the framework can be applied in both public and large business organizations that initiate large investment projects and aim for sustained project gains.

The rest of this paper is organized as follows. Section 2 highlights the theoretical background of project selection. Section 3 describes the research approach. In Section 4, the results of the literature analysis are presented. Section 5 summarizes the discussion on project selection. Section 6 provides conclusions and potential research directions.

\section{Theoretical Background}

Organizations require that the strategic selection process consider criteria such as financial impact, short cycle time, quality enhancement, risk reduction, [23], and sustainability [24]. In addition, the identification of sponsor, key stakeholders, resources, schedule, project interactions, key deliverables, budget, business unit, market, risk level, and impact are essential factors for the management of a project portfolio [25]. Therefore, the elicitation of processes, factors, and understanding of the impact of a specific nature of the project [26] is important in project selection.

The project selection and implementation require a continuous engagement of the management. Therefore, organizations should have managerial capabilities for the long-term success of projects. Managerial capabilities can be seen through the handling stakeholders and resource risk, for example, to obtain the expected project value [27]. These capabilities should be strengthened to support any process selection process that faces dynamic situations [28] in every selection cycle.

A framework for selecting a project portfolio is provided in [29] by focusing on pre-project and post-project processes. Another framework [11] provides an insight into the staging concept for project selection. The four steps selection model given in [24,30] and [31] consists of (1) identify and categorize projects; (2) evaluate and prioritize projects; (3) authorize projects and; (4) report and revise the project portfolio. Similarly, [32] and [33] propose a three-step process involving (1) evaluating and selecting the potential projects, (2) prioritizing candidate projects, and (3) estimating the available resource inventory. A five-step process proposed in [34] includes (1) formulating the investment strategy of the portfolio; (2) determining the projects' types that eligible for the portfolio; (3) assessing and prioritizing the candidate projects for the portfolio; (4) constructing a balanced portfolio that meets the investment goals, and; (5) monitoring and controlling the performance of the project portfolio. A three-stage framework is proposed in [33] by considering project options, key performance indicators (KPIs), and final selection for strategic project selection. Therefore, it is seen that authors have proposed 
selection frameworks for specific project situations; however, none of these frameworks explicitly consider managerial capabilities.

The selection process cannot be independent of the current and future capabilities of the organization. The standards in project management such as $([35,36])$ mention of the required project-related knowledge, which should be an integral part of project assessment and implementation. Therefore, the selection process should take into consideration the strategic issues that include the environment [23], social impact [24], risk mitigation [25], and sustainability goals [26]. In each step of project analysis, the assessment of managerial capabilities can provide knowledge on the suitability of the projects [27] regardless of the project type and project life cycle [37].

\section{Methodology}

A systematic literature review analysis approach, as mentioned in [38] for content-based analysis, is used in this paper. The combination of two analysis methods supports eliciting critical contributions of the literature in project selection and managerial capabilities in a transparent and unbiased manner. The analysis approach is given in Figure 1. As proposed in [39], this review starts with the research questions to develop a framework for selecting strategic projects. In the second step, the review period is focused primarily on the 2000 to 2018 period. Two key search terms were defined-'strategic project selection' and 'strategic project prioritization'. Google Scholar database was used for the initial search. This search was extended to other databases, like IEEE Xplore, ScienceDirect, Emerald Insight, Springer, Taylor and Francis, and Wiley. Most of the literature captured in these databases were also obtained in Google Scholar.

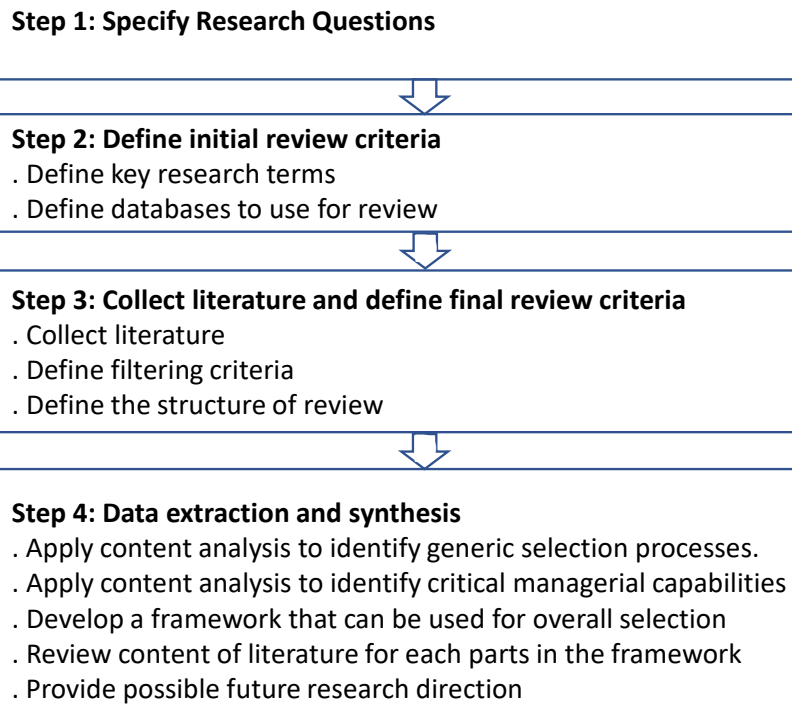

Figure 1. Analysis Approach.

In the third step, more than 300 literature were collected, and the filtering criteria were used to focus on various factors of strategic project selection. The common terms that emerged from the analysis were identification, categorization, evaluation, prioritization, balancing, and decision-making. Therefore, each article was group coded based on their contents.

In the fourth step, the collected literature was filtered by following the guidelines given in [40] and is shown in Table 1; therefore, providing validity for the collected literature. This filtering provided a list of 155 research related to strategic projects. Based on content analysis, 126 of these articles consider different aspects of risk, strategic analysis, governance, resource, stakeholder, and value analysis, 
as shown in Table 2. This type of method is also used in [41] for literature analysis using systematic literature review and content analysis to screen the literature.

Table 1. Screening criteria of the collected articles.

\begin{tabular}{|c|c|c|c|}
\hline$\#$ & Criteria & Description & $\begin{array}{l}\text { Criteria Checking } \\
\text { Example }\end{array}$ \\
\hline 1 & Descriptive validity & $\begin{array}{l}\text { The accuracy and objectivity of the } \\
\text { information gathered }\end{array}$ & $\begin{array}{l}\text { Does the article provide } \\
\text { enough description of } \\
\text { the reported results? }\end{array}$ \\
\hline 2 & Statistical conclusion validity & $\begin{array}{l}\text { The degree to which inferences } \\
\text { about the relationship among } \\
\text { project selection steps are logical } \\
\text { and in sequence. }\end{array}$ & $\begin{array}{l}\text { Does the article use the } \\
\text { right statistics with } \\
\text { proper sample sizes? }\end{array}$ \\
\hline 3 & Construct validity & $\begin{array}{l}\text { The objectivity of the article in terms } \\
\text { of studied strategic projects }\end{array}$ & $\begin{array}{l}\text { Does the article use data } \\
\text { validations, if applicable? }\end{array}$ \\
\hline 4 & External validity & $\begin{array}{l}\text { The extent to which the results } \\
\text { obtained from the study can be } \\
\text { generalized beyond the setting of } \\
\text { this study }\end{array}$ & $\begin{array}{l}\text { Does the article compare } \\
\text { and contrast multiple } \\
\text { case studies to enable } \\
\text { generalizability? }\end{array}$ \\
\hline
\end{tabular}

Table 2. Literature distribution across project selection and managerial capabilities.

\begin{tabular}{ccccccccc}
\hline$\#$ & Risk & Strategic & Governance & Resource Capability & Stakeholder & Value & Total \\
\hline 1 & $\begin{array}{c}\text { Identification and } \\
\text { Categorization }\end{array}$ & 8 & 6 & 9 & $*$ & 7 & $*$ & 30 \\
\hline 2 & Evaluation & 18 & $*$ & 16 & 15 & 9 & 11 & 69 \\
\hline 3 & $\begin{array}{c}\text { Prioritization and } \\
\text { Balancing }\end{array}$ & $*$ & $*$ & $*$ & 6 & 7 & 3 & 16 \\
\hline 4 & Decision Options & $*$ & 2 & $*$ & 2 & 4 & 3 & 11 \\
\hline & Total & 26 & 8 & 25 & 23 & 27 & 17 & 126 \\
\hline Managerial capabilities & 7 & 6 & 8 & 9 & 9 & 10 & $62^{+}$ \\
\hline
\end{tabular}

${ }^{+}$Notes: only significant works are mentioned; ${ }^{*}$ No significant works were identified in this group.

\section{Results of Literature Analysis}

\subsection{The Processes and Managerial Capabilities}

Based on content analysis and the discussion in Section 2, the generic processes for strategic project selections are grouped as the identification, categorization, evaluation, prioritization, balancing, and decision-making. Some of these generic processes are done either simultaneously or interactively. Therefore, they have been regrouped for generic processes as (1) identification and categorization, (2) evaluation, (3) prioritization and balancing, and (4) decision options. This answers the first research question, which leads to the second research question on the managerial capabilities (or organizational managerial capabilities) for the strategic project section.

The competence in ten management knowledge area is considered for project selection, planning, and development [35]. Although this competence is essential, specific managerial capabilities in the organization become important in the projects. For example, in many countries, public roads and development departments conceptualize the projects, recruit the consultants and contractors, finance the projects, and maintain them over time [42]. The authors could not locate literature that explicitly identifies a set of managerial capabilities critical to strategic projects. A compilation of six managerial capabilities is regarded as critical for strategic projects based on the literature analysis. It is mentioned that relevant managerial capabilities should also be considered in project selection [43], regardless of the project type and project life cycle. 
The third research question focuses on the link between the first two research questions. Managerial capabilities are to be considered while analyzing the project in a particular selection step. The review shows that the consideration of risk management capability is more critical in the strategic project selection as decision-makers have to consider the propensity of risk absorption or aversion before starting the project [44]. In contrast, value management is vital in the last three steps, as different value considerations could help compare the projects.

The outcome for the processes, various management factors, and their linkages, as obtained from the content analysis of the literature, are shown in Table 2. The table also shows that a smaller number of papers $(n=62)$ explicitly consider managerial capabilities. It shows that more researchers emphasize the need for managerial capabilities in the evaluation process, followed by the identification and categorization. The table also shows that all research collected for the analysis emphasizes that managerial capabilities are important in different project selection processes.

Table 3 provides a list of reviewed papers that consider different application sectors. Segregation of application area on review paper is also used in [41]. The papers reviewed here represent the construction sector, followed by transportation and information technology. The case studies in Table 3 are exclusive (without repetition).

Table 3. Literature distribution on strategic project selection across sectors.

\begin{tabular}{cc}
\hline Sector & Author $\left(\mathbf{n}=\mathbf{7 5 )}{ }^{*}\right.$ \\
\hline Construction $(\mathrm{n}=11)$ & {$[10,23,45-53]$} \\
\hline Energy $(\mathrm{n}=3)$ & {$[14,54,55]$} \\
\hline Environmental $(\mathrm{n}=2)$ & {$[56,57]$} \\
\hline Infrastructure $(\mathrm{n}=6)$ & {$[58-63]$} \\
\hline Information Technology $(\mathrm{n}=7)$ & {$[12,64-69]$} \\
\hline Manufacturing $(\mathrm{n}=4)$ & {$[28,33,70]$} \\
\hline Military $(\mathrm{n}=2)$ & {$[31,71]$} \\
\hline Oil and gas $(\mathrm{n}=3)$ & {$[22,72,73]$} \\
\hline Renewable energy $(\mathrm{n}=4)$ & {$[74-77]$} \\
\hline Transportation $(\mathrm{n}=7)$ & {$[17,42,78-82]$} \\
\hline R\&D $(\mathrm{n}=7)$ & {$[15,16,83-87]$} \\
\hline General or mixed sectors $(\mathrm{n}=19)$ & {$[1,2,5,7,11,24,26,29,32,43,88-96]$} \\
\hline
\end{tabular}

This literature review's focus is also to understand the possible extension of the work presented here and validate the research agenda based on the review. This leads to the fourth research question. In Section 6, some specific research related to the framework and overview of some generic research directions is presented.

\subsection{Proposed Framework of Strategic Project Selection}

The processes and the managerial capabilities obtained from the literature are organized in a framework (Figure 2), which gives the overall process for strategic project selection. There are two main parts in the framework: the selection steps and the managerial capabilities for long term benefits from the implemented projects. Therefore, the proposed framework encompasses sustainability in its entirety. As the framework is developed based on the organization's current and future capability to complete and sustain the project, each part of the framework should consider sustainability as a requirement. However, sustainability consideration becomes specifically important during the evaluation (sustainability in terms of using resources, the capability to make a positive impact), and decision options (sustainability in implementing projects). 


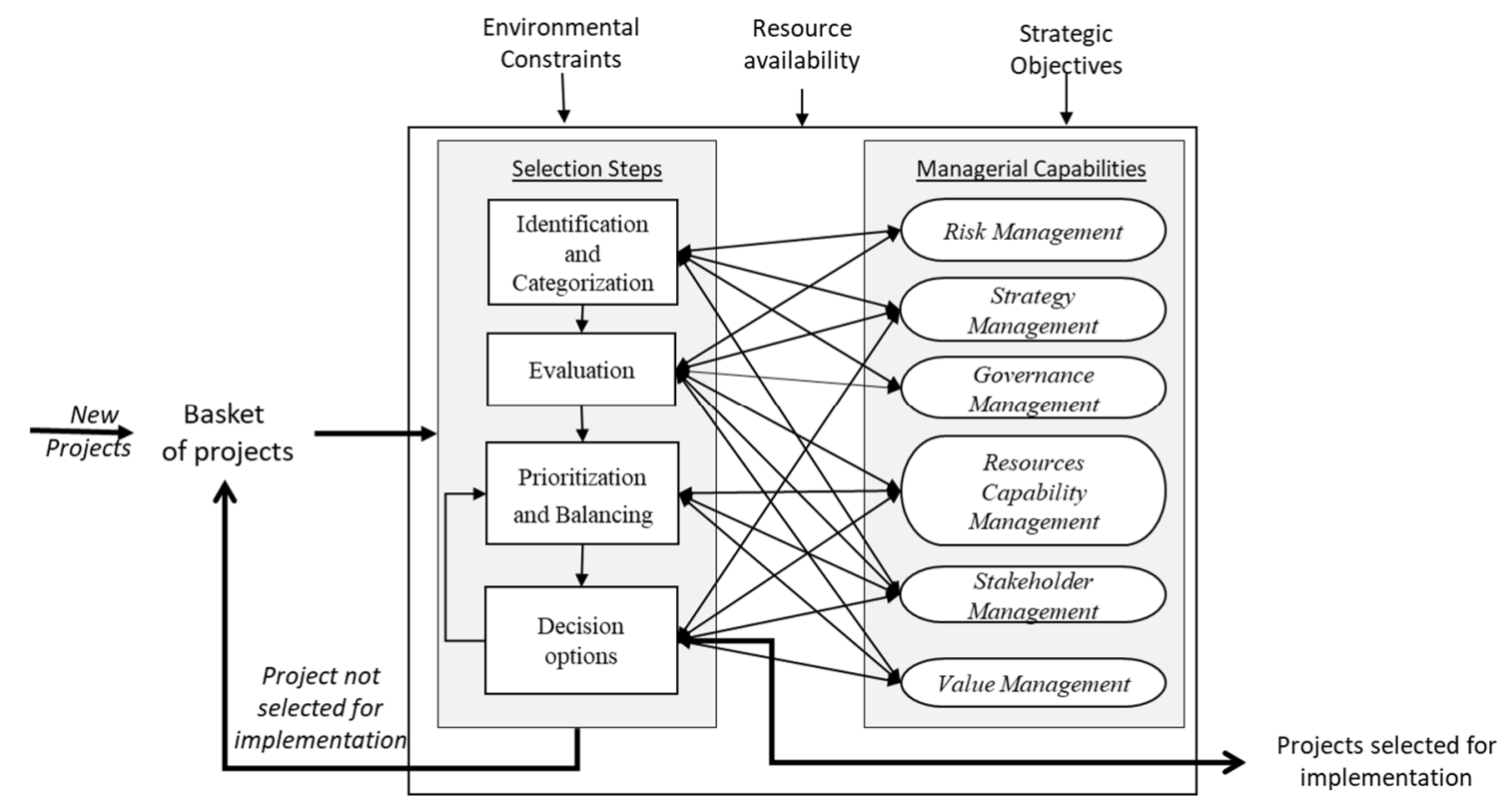

Figure 2. Framework for literature analysis for strategic project selection.

At the outset, the proposed framework is an extension and generalization of the work done in [29], which considers five discrete stages driven by organizational guidelines and resource availabilities. The framework in [29] considers project development, evaluation, and project completion out of the selection process. The framework proposed here is different from [29] in a few aspects. First, the proposed framework recognizes that there are constraints to the project selection process due to the prevailing environment during decision-making. In [29], it is mentioned that once a portfolio of projects goes through the selection process, the methodology applied to them may not be reviewed again. Essentially, this means that the results obtained from the last evaluation can be used for the next selection process. We argue that this is not necessarily true as the strategic project selection process is a periodic process, and it considers the long-term survivability of the project. Therefore, we have adopted the environment, strategy, and resource capacity as constraints that influence the project's outcome. Second, the proposed framework also shows some critical managerial capabilities to guide the selection. These capabilities are different from the strategy development guidelines and resources mentioned in [29]. Third, the proposed framework considers the dynamics of the capabilities and the business environment. The capabilities have to be considered in more than one-step of the selection process and with different managerial capability levels. For example, value management during the evaluation process can be based on the gross level of data used across the projects. However, as the number of selected projects is much less during the decision options process, more data and more intense evaluation would be required for value analysis. The proposed framework is also used for content-based literature analysis. Therefore, the framework development and usage for literature analysis are consistent with that presented in [21].

Authors recommend focusing on strategic issues that include the environment [56], social impact [57], risk mitigation [78], and high-level sustainability goals [37]. These issues and goals may pose constraints to the selection process. For example, during and after a pandemic situation, project selection can be different due to the business environment and strategic objectives faced by an organization. In addition, the project selection process for meeting a specific goal, such as hosting the World Cup, is faced with different constraints than projects for long-term sports development. The importance of constraints in projects is also mentioned in $([37,78])$. Therefore, consideration of project constraints is important [88] in project selection. Therefore, based on the literature analysis and the 30 plus years of experience of the first two authors in government and large business projects, 
it can be mentioned that at least the three constraints, namely, environmental, resources, and strategic objectives, as shown in the upper part of Figure 2, should be considered for project selection.

\subsection{Literature Analysis for the Selection Steps}

This section describes the four groups of processes identified in Figure 2. In each process, one more aspect of the project may be examined in order to lead to the next step of the selection process. The use of different criteria for processes is suggested in [89]. A list of 48 criteria, including technology maturity, capital costs, job creation, social acceptance, operating life, social benefit, net present value, and political acceptance, is given in [54]. It is to be noted that the selection steps adopt a funneled process. That means the list of projects is reduced in each step of a selection cycle. Unsuccessful projects are dropped out for consideration in the next cycles.

\subsubsection{Identification and Categorization}

If the right type of projects is not considered for the selection, it can create a lost opportunity, as the whole selection process would depend on the identified list of projects. These projects would have to be categorized based on organizational strategic objectives [25]. As projects usually have multiple stakeholders, they may pose conflicting priorities; therefore, governance or responsibilities, privileges, and benefits must be established to identify and categorize the basket of projects.

Authors have mentioned that projects need to be screened based on criteria such as financial impact, short cycle time, quality enhancement, risk reduction, resources, and long term impact $([23,45,90]$ or the creation of subsequent opportunities [24]. Identification and categorization can be different in public and business organizations. A project in a business organization provides strategic integration that enhances corporate competition and profitability, while projects in the public sector aim at positive social impact and welfare.

A project can be categorized in terms of ownership, application area or product, timing, geography, risk, the uncertainty level, customer complexity, contracting [25], and the requirements of internal and external stakeholders [46]. Other categorization criteria can be profitability, competence improvement, legal compliance, increased market share, process improvement, and business requirements (e.g., $[5,25,58,79]$ ). There is only a small emphasis on qualitative factors such as stakeholder relationships and trust in this step [59].

\subsubsection{Project Evaluation}

Various methods have been recommended by authors to evaluate categorized projects. In some projects such as land-based projects, evaluation can focus on geographical features [26], whereas in others, financial factors may be more important. Scoring methods may also be used for evaluation based on criteria like risk, capabilities, governance, stakeholder management, and value management. The choice of criteria is to be based on its applicability across the project categories [97]. Authors have proposed the DEA based multi-objective method and evolution algorithm [54], cost-benefit analysis and risk analysis [91], risk analysis, and scenario analysis [72], and the Delphi with MICMAC analysis method [47] for project evaluation. In general, regardless of the business sector, based on [73], the criteria for evaluating projects are grouped into four different factors, as shown in Table 4. For each of these factors, techniques for analysis can also be different, as shown in Table 5. The list of techniques is also proposed in the literature $([29,98-101])$. The analysis also shows that the evaluation process should consider all managerial capabilities. Only those projects supported by the organization's managerial capabilities can be taken for prioritization and balancing. 
Table 4. Criteria for project categorization.

\begin{tabular}{ccc}
\hline Factors & Potential Criteria & Authors \\
\hline Business & $\begin{array}{c}\text { Ability to align with country policy } \\
\text { Ability to align with the sector policy } \\
\text { Ability to align with strategy and objectives } \\
\text { Priority } \\
\text { Cost/benefit }\end{array}$ & {$[2,48,49,60,74,93]$} \\
Market & Market capacity \\
& Market growth rate \\
& $\begin{array}{c}\text { Market competition } \\
\text { Market profitability }\end{array}$ & {$[50,83,94]$} \\
Resource availability & Capital resource and budget \\
& Human resource \\
& Resource from the supply chain \\
Outside technical support & {$[1,51,75,83,102]$} \\
\hline Risk & Ability to balance organization growth and minimal risk & {$[51,52,54,103]$} \\
\hline
\end{tabular}

Table 5. Some models used in project selection; some of these models are also listed in [73].

\begin{tabular}{|c|c|c|c|}
\hline Techniques & Description & Possible Techniques & Authors \\
\hline Benefits Measurement & $\begin{array}{l}\text { Provides metrics rather than tools } \\
\text { and techniques to be used as inputs } \\
\text { for ranking or scoring. It is the most } \\
\text { cited approach in the literature. } \\
\text { The decision-maker weights all } \\
\text { projects, and then sorts these } \\
\text { projects on the basis of benefits. }\end{array}$ & $\begin{array}{l}\text { Consensus models } \\
\text { Benefits contribution } \\
\text { (economic models) } \\
\text { Cost-benefit } \\
\text { Risk analysis } \\
\text { Productivity index } \\
\text { Ordinal ranking } \\
\text { Pairwise comparison } \\
\text { Multiple criteria and multiple } \\
\text { attribute models }\end{array}$ & $\begin{array}{c}{[1,2,48,51,64-66,} \\
73,104,105]\end{array}$ \\
\hline Knowledge-based model & $\begin{array}{l}\text { Improper projects are eliminated } \\
\text { based on scoring techniques. } \\
\text { However, excluded projects may } \\
\text { include a pre-requested } \\
\text { critical project. }\end{array}$ & $\begin{array}{l}\text { Top-down methodologies } \\
\text { Systems approaches }\end{array}$ & {$[50,65]$} \\
\hline Strategic Planning & $\begin{array}{l}\text { Use bubble charts to balance the } \\
\text { portfolio. This provides a graphical } \\
\text { representation of potential projects } \\
\text { and their properties and conditions. } \\
\text { It also provides tools for project } \\
\text { classification using decision tree } \\
\text { cluster analysis to process } \\
\text { qualitative and quantitative data. } \\
\text { A sophisticated model of these } \\
\text { techniques can be beneficial } \\
\text { in a portfolio. }\end{array}$ & $\begin{array}{c}\text { Cognitive emulation } \\
\text { Regression } \\
\text { Decision trees } \\
\text { Expert systems } \\
\text { Portfolio maps } \\
\text { Cluster analysis }\end{array}$ & {$[64,92,106]$} \\
\hline Marketing Research & $\begin{array}{l}\text { Provide estimations of the market, } \\
\text { cost, and price; However, this } \\
\text { method cannot provide a full image } \\
\text { of the alternatives, cost, and risk. }\end{array}$ & $\begin{array}{l}\text { Consumer panels } \\
\text { Focus groups } \\
\text { Perceptual maps } \\
\text { Preference mapping }\end{array}$ & {$[67,107]$} \\
\hline $\begin{array}{l}\text { Mathematical and } \\
\text { Programming }\end{array}$ & $\begin{array}{l}\text { One or multiple objectives are used } \\
\text { on projects. The technique gives the } \\
\text { optimal portfolio under different } \\
\text { constraints. This method uses a } \\
\text { mathematical base to assign weighs } \\
\text { and ranks to the project portfolio. } \\
\text { The objective could be in terms of } \\
\text { return or employability, and the } \\
\text { techniques for analysis could } \\
\text { include the programming methods. }\end{array}$ & $\begin{array}{l}\text { Average rate of return } \\
\text { Discounted cash flow } \\
\text { Internal rate of return } \\
\text { Profitability index } \\
\text { Integer programming } \\
\text { Linear/nonlinear } \\
\text { programming } \\
\text { Dynamic programming }\end{array}$ & {$[2,76,83-85]$} \\
\hline
\end{tabular}




\subsubsection{Prioritization and Balancing}

Project prioritization should be based on resource availability and long-term organizational benefits $([28,86,108])$. Resource capability management ensures that needed resources and capabilities are available on schedule with minimum possible cost and lowest possible loss of long-term opportunities. However, many subjective situations, such as changing market needs, can lead to a change in prioritization. Therefore, project prioritization should consider the dynamic trade-off between the 'projects' value and resources (resources capability management) [27]. Projects should be prioritized for maximizing the combined outcomes of the selected projects by balancing organizational capacities [109]. Techniques recommended for prioritization in the literature are goal programming $([61,62])$, the process failure modes and effect analysis (PFMEA) [70], the Likert based criteria weightage method [31], the Monte-Carlo simulation-based data envelopment analysis method (DEA) [80], simulation-based models [81], and a resource-constrained DEA [15]. Qualitative methods are also recommended, such as the Delphi method or a decision tree method ([71,82]), a fuzzy quality function deployment (QFD), and the DEA [66], a harmony search algorithm [95]. However, not all methods are applicable to all project situations.

Prioritized projects should be balanced with the resources at hand and the importance placed by the stakeholders on the project. The balancing decision and expected results (e.g., review cycles, schedule performance metrics, and required outcomes) from the project also fall under this step.

\subsubsection{Decision Options}

Developing decision options or alternatives could be intrinsic (project and project organization based) or extrinsic (project performance criteria such as legal and technological aspects and dynamics of the market environment). Different criteria are proposed for decision-making, such as sustainability, meeting social objectives, capital availability, and political situations [31]. Similarly, a sustainability-based approach with economic, environmental, and social criteria using a fuzzy logic model is given in [33]. A game-based model to analyze project payoff or management commitment is given in [90]. The decision-makers can use organization based qualitative criteria; for example, top management support in developing the decision options for the final selection of the project portfolio [68]. Some authors also recommend the use of project database and group decision-making $([29,96])$.

It should be noted that the projects, once implemented, need continuous monitoring and control [110] and should have time-bound reports [111] for evaluation. These reports can provide feedback for adjustments or developing managerial interactions [29], which are essential for the next set of projects.

\subsection{Literature Analysis of Managerial Capabilities and Linkages}

This section addresses the research questions 2 and 3 on the managerial aspects and their importance in the selection process. The importance of organizational capabilities has two main aspects. First, the selection process is limited by the organization's managerial capabilities. Second, the selection process will show that the current capabilities may not be enough for new types and scales of strategic projects. For the second aspect, the organization should also invest in the development of capabilities. Therefore, the knowledge on the inventory of managerial capabilities and their relation with the selection steps becomes essential. The six managerial capabilities of an organization identified in the literature analysis are discussed below.

\subsubsection{Risk Management}

Risk is involved primarily in the identification and the evaluation steps of project selection. Risk management, project complexity, governance and control, and project uncertainty are essential for projects [112]. Risk management has interdependencies and becomes complex when more projects 
and parties are involved [113]. Capability to manage risk enhances project value [114]; therefore, project risk profile [77] and its influence on project performance [115] must be analyzed. The authors recommend integrated risk assessment and management $([69,116,117])$, and the development of a risk management plan for project success [118]. Therefore, although preliminary risk assessment might have to be done during the identification process, its impact on the projects must be assessed during the evaluation phase of the project.

\subsubsection{Strategy Management}

Strategy management requires decision-makers to relate organizational learning, adaptability, and employee development to drive project success [72] and focus on resource allocations in changing economic, social, political, or environmental situations [6]. The importance of strategic management and planning for projects is highlighted in $([53,119,120])$. Strategy management balances constraints posed by resource allocations [121]. Therefore, organizations should assess their strategies for different business environment scenarios [122]. In the private sector, strategic project selection is positively correlated with senior management's expectations and 'stakeholders' expectations [123]; therefore, strategic management requires assessing internal resources and external forces on the organization. Strategy management is most relevant in identifying, evaluating, and using a decision option analysis for final selection in the framework. This supports the fact that any employed strategy should consider the current organizational mission and the vision for the future.

\subsubsection{Governance Management}

Governance management relates to policies, rules, established and potential relationships, stakeholder engagement, continuity of organizational structure, and provisions for facilitating external stakeholders in the project's design. Organizational governance, therefore, focuses on the ability to control and coordinate project processes [124], organizational accountability, the capability to promote improvement in project performance [125], and good financial management [126]. Therefore, prioritizing projects based on funding, supporting public expectations on service, resilience, the involvement of multiple stakeholders, understanding the changes, and adapting to the change becomes essential [125].

Governance management is critical in decision-making structure, benefits management, and transparency $([59,126-128])$ for the selection and implementation of the projects [129], leading to project success [119]. The four key governance factors to enhance project performance and organizational value [130] are (i) the selection of the right projects, (ii) maintaining a direct relationship between the stakeholders and the project manager, (iii) monitoring and strategic reporting of projects, and (iv) an effective governance system. However, only good project governance leads to reasonable risk and quality management [131].

In the proposed framework, the importance of governance management in the first two steps of strategic projects is emphasized. Among the factors, these steps should consider governance aspects like stakeholder relationships, investment availability, and transparency in projects [87].

\subsubsection{Resources Capability Management}

An organization's capability can be understood through its ability to support project operations ([132,133]). Balanced resource management helps in the better allocation and the sustainability of resource use [134]. The availability of required resources plays a crucial role in expected returns from the projects [16]. A productive capacity and capability management also help to balance organizational potential with organizational goals [16]. Organizational capability to manage resources can be enhanced if the knowledge of rules, standards, norms, and policies are communicated in the organization [135].

In the proposed framework, it is seen that the resource capability impacts project evaluation, prioritization, and the final decision-making step. The ability to respond to the changes in projects [136] 
and reorganize resources to obtain project goals through the holistic approach [137] is a critical organizational capability.

Some authors have studied resource allocations by using analytical models. For example, multi-attribute resource-leveling [138] and bi-criteria modeling consider fairness and expected benefits for budget allocation to projects in different departments [139]. However, the research on the resources capability management for strategic project selection seems to be lacking to a great extent.

\subsubsection{Stakeholder Management}

Stakeholder involvement is an essential aspect of projects as it describes their primary role in defining their criteria for the identification and evaluation of the projects. Stakeholder analysis is important to gain funding, elicit requirements, and develop project success $([3,118])$. Therefore, the involvement of stakeholders from the beginning of the selection process is important. The stakeholder's role extends to other steps of the selection process as well. A good stakeholder analysis is important for stakeholder management and engagement $([63,140,141])$. In complex project situations, the project team may need continuous involvement and support of the stakeholders $([141,142])$. Such involvement will help support projects when there are concerns about evolving needs and project requirements [143].

The success of projects is hinged on the owner, manager, and the funder of the projects $([144,145])$. Therefore, organizational capability on analyzing stakeholders in terms of their stake holding (the analysis of impact) and influencing degree (on their project-related attitude) [6] is significant to project success [59].

\subsubsection{Value Management}

Value in project management focuses on cost and schedule and project objectives [146]. Value management also means developing alternate options and re-arranging project returns with the intended results while ensuring the project outputs [118]. Value consideration becomes important in project selection ([43,147-150]). Various qualitative, conceptual, and quantitative methods used by different authors for value analysis are mentioned in [8]. This type of analysis is done for a single project case basis; however, the authors mention the need to integrate value management aspects in the project selection process itself $[8,151,152]$.

The value analysis of projects should focus on factors like 'stakeholders' goal, their commercial success, and achievement in technological development [150]. Stakeholders should be informed that projects do not accrue the same value for different stakeholders simultaneously due to the nature of the project or due to the changing project environment [27]. However, projects can provide value in terms of improved processes and productivity [150], essentially focusing on longer-term gains [55].

In the proposed framework, value management is important in three steps of project selection: project evaluation, prioritization and balancing, and the decision options. In these phases, it is necessary to involve the stakeholder to develop a shared understanding for the creation and delivery of project values that can relate to economic, social, environmental, technological development, or even the aesthetic aspects [151]. Therefore, setting value targets and correlating them with the projects become essential here. It is also mentioned that value management requires an understanding of project assets outcomes, their operability, and their impact on the current operation [152]. Therefore, organizational capability for assessing, planning, controlling, and obtaining project value becomes very important.

\section{Discussion}

Strategic projects provide long-term benefits. These projects have to be sustainable, either in terms of their development or in terms of operation. Therefore, their selection should focus on the project-specific selection criteria and the organization's long-term managerial capabilities on governance, risk management, resource management, stakeholder management, and value management. These organization capabilities are crucial during the selection, but they can also 
have detrimental repercussions during the implementation and the continuity of project outcomes. Literature analysis shows the available selection frameworks mainly focus on the project application area. The frameworks also do not explicitly consider a set of managerial capabilities that drive the strategic project selection process. Also, mapping of the relevant managerial capabilities in each step of the selection process is not considered in the literature. Therefore, the paper contributes to developing a generic stepped method in which the dynamics of decision-making and the analysis of organizational capability are important.

The four research questions answered in the paper provide the processes, organizations' managerial capabilities, and managerial capabilities relevant to the project selection steps. Managerial capability leads to organizational strength, and there are some specific steps where one or the other managerial capabilities become more important. The literature analysis shows that risk management, strategy management, governance management, and stakeholder should be assessed during identification and project categorization. The assessment of all managerial capabilities is vital in the evaluation step. Similarly, resources, stakeholders, and value are important considerations for prioritization and balancing of projects. For the decision making step of strategic project selection, strategies, resources, stakeholders, and value management are essential. However, during the final step, decision-makers can focus on all of the above managerial capabilities to choose an alternative project.

It is clear from the literature analysis that the linkages of managerial capabilities and the selection steps are not a transitive closure but some interrelationship based digraph that considers different levels of criticality. The organizational capabilities are usually related, which means that an organization with a strategic management capability may also have a value management capability. However, the literature mostly treats these capabilities in silos. Such a silo treatment may be superficial, as organizational capabilities are intertwined and affect the selection process.

Strategic projects are conceptualized and developed both in public and in private sectors. While the public sector projects are more accountable to the public in terms of its promises and are linked with long-term plans, private sector projects are usually sponsored at the highest level of an organization. Changing the strategy orientation can be based on organizational leadership and the business environment in the private sector. Therefore, as mentioned in the framework, the strategy and the environment are essential constraints in the decision-making process.

The results of this study show that managerial capabilities are significant predictors of a successful project selection process. For senior management and decision-makers, the project selection should be integrated with corporate management practices to ensure vitality, sustainability, and practical tangible and intangible benefits.

\section{Conclusions and Research Direction}

The steps, managerial capabilities, and strategic project selection techniques are provided through a systematic review using the content analysis method. One of the paper's main contributions is the development of a project selection framework, obtained through the content analysis, which shows that strategic project selection can be covered through the four generic processes. Based on the review, it is shown that the feasibility of obtaining sustained project value depends on the overarching managerial capabilities of an organization. Based on the review, six critical managerial capabilities of an organization have been identified and discussed. It is also shown that appropriate managerial capabilities must be assessed and utilized in the selection steps.

The review shows that both qualitative and quantitative models can be used in project selection steps, but they have to be correlated with the applicable managerial capabilities. The proposed strategic project selection framework is not a prescription but a suggestion for systematic analysis of strategic projects. Based on the review, it is recommended that the analysis of management capabilities should form an integral part of the project selection process. It is identified that the perspectives of risk, quality, stability, sustainability, governance, resources, organizational strategy, value, and stakeholder management are essential in project selection. 


\section{Possible Research Direction}

A few considerations are mentioned below for possible future research in strategic project selection based on the review.

- There can be competing strategies, such as sustainability and resource availability, need for services and cost optimization, and social well-being and near-term project outcomes for project selection. While more quantitative aspects can be considered in the earlier steps of strategic project analysis, competing strategies can be considered mainly in the decision option step. A decision support system that uses suitable multi-objective analysis or multi-criteria analysis can be developed to support the overall process of strategic project selection. One comprehensive decision support system with multiple objectives (cost, energy, and employment) is given in [153]. Such a decision support system for project selection is also mentioned in [29]. Another type of decision support is also mentioned in [96]. The decision support system can incorporate a library of relevant methodologies and libraries to help develop various decision options.

- Each step in the strategic project selection has implications from a managerial perspective. The current frameworks do not explicitly consider this integrative analysis of managerial capabilities. Some of the research on individual managerial capability for projects are given in $([6,8,9,13,18,122])$. There are some quantitative methods reported by authors for individual managerial capabilities. For example, the use of survey method is used for risk analysis $([11,13,103])$, stakeholder prioritization [12], and resource analysis $([15,87,138])$. Therefore, the research can focus on developing and integrating quantitative methods or frameworks to assess managerial strength and link them to appropriate steps to select projects. Some basic works for such methods have been mentioned in $([33,64,67,85,97])$. However, their applicability and extension to integrate multiple managerial capabilities would need rigorous research. If such a method can be developed, it can provide an avenue to simulate project scenarios based on selection steps and managerial capabilities for a dynamic decision-making situation.

- Even when a single managerial capability is considered, for example, value management, they are often focused on a single project [8] and may consider financial or sustainability. However, in a strategic project situation, the value management aspect should be holistic and consider value obtained through projects. While financial gain can be more important during the earlier stage of project selection, sustainability can be more important during the decision-making step [152]. Therefore, further research can focus on the integrated impact of individual managerial capabilities. Research can also be focused on developing quantitative models to assess benefits on a variety of performance measures like sustainability, social factors, and ecological factors [8].

- Another area of research can be extended to analyze resource competition for the projects. Resource competition becomes important in multiple projects due to inherent problems on project time and cost performance against the need to optimize the limited resources. One such method is also proposed in [90] by using game theory models. Generalizing and extending such models can be useful for the researchers considering selecting a strategic project.

- The six managerial capabilities that assess organizational strength on selecting and handling strategic projects are based on the emphasis given in the literature. The authors could not locate additional managerial capabilities that might have been used in practice for strategic project selection. Identifying managerial performance measures and clustering them for detailed analysis can provide new managerial knowledge for strategic project selection. Empirical studies of large-scale cross-country projects can support this type of study.

Author Contributions: Conceptualization: K.M.A.-S., S.P., G.M.A; methodology: K.M.A.-S., S.P.; validation: K.M.A.-S., S.P.; formal analysis: K.M.A.-S., S.P.; investigation: K.M.A.-S., S.P., G.M.A.; resources: K.M.A.-S., S.P.; data curation: K.M.A.-S., S.P.; writing original draft and preparation: K.M.A.-S., S.P., G.M.A.; Writing-Review and Editing: K.M.A.-S., S.P., G.M.A.; visualization: K.M.A.-S., S.P.; supervision: S.P., G.M.A.; project administration: S.P., G.M.A. All authors have read and agreed to the published version of the manuscript. 
Funding: This research received no external funding.

Conflicts of Interest: The authors declare no conflict of interest.

\section{References}

1. Costantino, F.; di Gravio, G.; Nonino, F. Project selection in project portfolio management: An artificial neural network model based on critical success factors. Int. J. Proj. Manag. 2015, 33, 1744-1754. [CrossRef]

2. Dutra, C.C.; Ribeiro, J.L.D.; de Carvalho, M.M. An economic-probabilistic model for project selection and prioritization. Int. J. Proj. Manag. 2014, 32, 1042-1055. [CrossRef]

3. Ogunlana, S.O. Beyond the 'iron triangle': Stakeholder perception of key performance indicators (KPIs) for large-scale public sector development projects. Int. J. Proj. Manag. 2010, 28, 228-236.

4. Martinsuo, M.; Dietrich, P. Public sector requirements towards project portfolio management. In Proceedings of the PMI Research Conference, Washington, DC, USA, 14 July 2002; pp. 361-370.

5. Crawford, L.; Hobbs, B.; Turner, J.R. Aligning capability with strategy: Categorizing projects to do the right projects and to do them right. Proj. Manag. J. 2006, 37, 38-50. [CrossRef]

6. Zwikael, O.; Smyrk, J.R. Stakeholder Management. In Project Management; Springer: Berlin/Heidelberg, Germany, 2019; pp. 85-102.

7. Villafáñez, F.; Poza, D.; López-Paredesa, A.; Pajaresa, J.; Acebes, F. Portfolio scheduling: An integrative approach of limited resources and project prioritization. J. Proj. Manag. 2020, 5, 103-116. [CrossRef]

8. Martinsuo, M.; Killen, C.P. Value Management in Project Portfolios: Identifying and Assessing Strategic Value. Proj. Manag. J. 2014, 45, 56-70. [CrossRef]

9. Müller, R.; Zhai, L.; Wang, A. Governance and governmentality in projects: Profiles and relationships with success. Int. J. Proj. Manag. 2017, 35, 378-392. [CrossRef]

10. Karamoozian, A.; Wu, D.; Chen, C.L.P.; Luo, C. An Approach for Risk Prioritization in Construction Projects Using Analytic Network Process and Decision Making Trial and Evaluation Laboratory. IEEE Access 2019, 7, 159842-159854. [CrossRef]

11. Dixit, V.; Tiwari, M.K. Project portfolio selection and scheduling optimization based on risk measure: A conditional value at risk approach. Ann. Oper. Res. 2019, 285, 9-33. [CrossRef]

12. Ligardo-Herrera, I.; Navarro, T.G.; Gonzalez-Urango, H. Application of the ANP to the prioritization of project stakeholders in the context of responsible research and innovation. Cent. Eur. J. Oper. Res. 2018, 27, 679-701. [CrossRef]

13. Read, L.; Madani, K.; Mokhtari, S.; Hanks, C. Stakeholder-driven multi-attribute analysis for energy project selection under uncertainty. Energy 2017, 119, 744-753. [CrossRef]

14. Kudratova, S.; Huang, X.; Kudratov, K.; Qudratov, S. Corporate sustainability and stakeholder value trade-offs in project selection through optimization modeling: Application of investment banking. Corp. Soc. Responsib. Environ. Manag. 2019, 27, 815-824. [CrossRef]

15. Cook, W.D.; Green, R.H. Project prioritization: A resource-constrained data envelopment analysis approach. Socio Econ. Plan. Sci. 2000, 34, 85-99. [CrossRef]

16. Wang, B.; Song, Y.; Qin, Y.; Jia, L.; Feng, J.; An, M.; Diao, L. Reinvestment Strategy-Based Project Portfolio Selection and Scheduling with Time-Dependent Budget Limit Considering Time Value of Capital; Springer: Berlin/Heidelberg, Germany, 2016.

17. Li, Y.; Han, Y.; Luo, M.; Zhang, Y. Impact of Megaproject Governance on Project Performance: Dynamic Governance of the Nanning Transportation Hub in China. J. Manag. Eng. 2019, 35, 05019002. [CrossRef]

18. Naaranoja, M.; Haapalainen, P.; Lonka, H. Strategic management tools in projects case construction project. Int. J. Proj. Manag. 2007, 25, 659-665. [CrossRef]

19. Pokharel, S.; Mutha, A. Perspectives in reverse logistics: A review. Resour. Conserv. Recycl. 2009, 53, $175-182$. [CrossRef]

20. Caunhye, A.M.; Nie, X.; Pokharel, S. Optimization models in emergency logistics: A literature review. SocioEcon. Plan. Sci. 2012, 46, 4-13. [CrossRef]

21. Xu, Z.; Elomri, A.; Pokharel, S.; Mutlu, F. The Design of Green Supply Chains under Carbon Policies: A Literature Review of Quantitative Models. Sustainability 2019, 11, 3094. [CrossRef] 
22. Rebeeh, Y.; Pokharel, S.; Abdella, G.M.; Hammuda, A. A framework based on location hazard index for optimizing operational performance of emergency response strategies: The case of petrochemical industrial cities. Saf. Sci. 2019, 117, 33-42. [CrossRef]

23. Mahdavi, A.; Naderpajouh, N.; Choi, J.; Ketabi, A.B.; Hastak, M.; Cui, Q. Dynamics of project selection and growth in project-based organizations. Int. J. Constr. Manag. 2019, 1-18. [CrossRef]

24. Benaija, K.; Kjiri, L. Project portfolio selection: Multi-criteria analysis and interactions between projects. arXiv Preprint 2015, arXiv:1503.05366.

25. Crawford, L.; Turner, J.; Hobbs, B. Project Categorization System and Their Use Project Categorization System and Their Use in Organisations: An Empirical Study. In Proceedings of the In Project Management Institute Research Conference, London, UK, 11-14 July 2004.

26. Muchová, Z.; Petrovič, F. Prioritization and Evaluation of Land Consolidation Projects-Žitava River Basin in a Slovakian Case. Sustainability 2019, 11, 2041. [CrossRef]

27. Patanakul, P. Key attributes of effectiveness in managing project portfolio. Int. J. Proj. Manag. 2015, 33, 1084-1097. [CrossRef]

28. Jarvenpaa, E.; Lanz, M.; Siltala, N. Formal Resource and Capability Models supporting Re-use of Manufacturing Resources. Procedia Manuf. 2018, 19, 87-94. [CrossRef]

29. Archer, N.; Ghasemzadeh, F. An integrated framework for project portfolio selection. Int. J. Proj. Manag. 1999, 17, 207-216. [CrossRef]

30. Blichfeldt, B.S.; Eskerod, P. Project portfolio management-There's more to it than what management enacts. Int. J. Proj. Manag. 2008, 26, 357-365. [CrossRef]

31. Group Capt. Surapon Puthamont; Charoenngam, C. Strategic project selection in public sector: Construction projects of the Ministry of Defence in Thailand. Int. J. Proj. Manag. 2007, 25, 178-188. [CrossRef]

32. Moustafaev, J. Delivering Exceptional Project Results: A Practical Guide to Project Selection, Scoping, Estimation and Management; J. Ross Publishing: Plantation, FL, USA, 2010.

33. Ma, J.; Harstvedt, J.D.; Jaradat, R.; Smith, B. Sustainability Driven Multi-Criteria Project Portfolio Selection under the Uncertain Decision-Making Environment. Comput. Ind. Eng. 2020, 140, 106236.

34. Wysocki, R.K. Effective Project Management: Traditional, Adaptative, Extreme; John Wiley and Sons: Hoboken, NJ, USA, 2011.

35. PMI. A Guide to the Project Management Body of Knowledge PMBOK(R) Guide; Project Management Institute: Philadelphia, PA, USA, 2017.

36. PMI. The Standard for Portfolio Management; Project Management Institute: Philadelphia, PA, USA, 2017.

37. Aarseth, W.; Ahola, T.; Aaltonen, K.; Økland, A.; Andersen, B. Project sustainability strategies: A systematic literature review. Int. J. Proj. Manag. 2017, 35, 1071-1083. [CrossRef]

38. Tranfield, D.; Denyer, D.; Smart, P. Towards a Methodology for Developing Evidence-Informed Management Knowledge by Means of Systematic Review. Br. J. Manag. 2003, 14, 207-222. [CrossRef]

39. Klein, G.; Müller, R. Literature Review Expectations of Project Management Journal ${ }^{\circledR}$. Proj. Manag. J. 2020, 51, 239-241. [CrossRef]

40. Farrington, D. Methodological quality standards for evaluation research. Ann. Am. Acad. Political Soc. Sci. 2003, 587, 49-68. [CrossRef]

41. Thonemann, N.; Schulte, A.; Maga, D. How to Conduct Prospective Life Cycle Assessment for Emerging Technologies? A Systematic Review and Methodological Guidance. Sustainability 2020, 12, 1192. [CrossRef]

42. Ivanović, I.D.; Grujičić, D.; Macura, D.; Jovic, J.; Bojovic, N. One approach for road transport project selection. Transp. Policy 2013, 25, 22-29. [CrossRef]

43. Müller, R.; Martinsuo, M.; Blomquist, T. Project Portfolio Control and Portfolio Management Performance in Different Contexts. Proj. Manag. J. 2008, 39, 28-42. [CrossRef]

44. Issa, U.H.; Mosaad, S.A.; Hassan, M.S. Evaluation and selection of construction projects based on risk analysis. Structures 2020, 27, 361-370. [CrossRef]

45. Eken, G.; Bilgin, G.; Dikmen, I.; Birgonul, M.T. A lessons-learned tool for organizational learning in construction. Autom. Constr. 2020, 110, 102977. [CrossRef]

46. Nguyen, T.H.D.; Chileshe, N.; Rameezdeen, R.; Wood, A. External stakeholder strategic actions in projects: A multi-case study. Int. J. Proj. Manag. 2019, 37, 176-191. [CrossRef]

47. Han, Q.; Zhu, Y.; Ke, G.; Hipel, K. Public private partnership in brownfield remediation projects in China: Identification and structure analysis of risks. Land Use Policy 2019, 84, 87-104. [CrossRef] 
48. Dobrovolskienè, N.; Tamošiūnienè, R. An index to measure sustainability of a business project in the construction industry: Lithuanian case. Sustainability 2016, 8, 14. [CrossRef]

49. Pangsri, P. Application of the Multi Criteria Decision Making Methods for Project Selection. Univers. J. Manag. 2015, 3, 15-20. [CrossRef]

50. Taylan, O.; Bafail, A.O.; Abdulaal, R.M.; Kabli, M.R. Construction projects selection and risk assessment by fuzzy AHP and fuzzy TOPSIS methodologies. Appl. Soft Comput. 2014, 17, 105-116. [CrossRef]

51. Kaiser, M.G.; El Arbi, F.; Ahlemann, F. Successful project portfolio management beyond project selection techniques: Understanding the role of structural alignment. Int. J. Proj. Manag. 2015, 33, 126-139.

52. Mohagheghi, V.; Mousavi, S.M.; Vahdani, B. A New Optimization Model for Project Portfolio Selection Under Interval-Valued Fuzzy Environment. Arab. J. Sci. Eng. 2015, 40, 3351-3361. [CrossRef]

53. Dahmas, S.; Li, Z.; Liu, S. Solving the difficulties and challenges facing construction based on concurrent engineering in Yemen. Sustainability 2019, 11, 3146. [CrossRef]

54. Wu, Y.; Xu, C.; Ke, Y.; Li, X.; Li, L. Portfolio selection of distributed energy generation projects considering uncertainty and project interaction under different enterprise strategic scenarios. Appl. Energy 2019, 236, 444-464. [CrossRef]

55. Al-Saleh, Y.M.; Taleb, H.M. The Integration of Sustainability within Value Management Practices: A Study of Experienced Value Managers in the GCC Countries. Proj. Manag. J. 2010, 41, 50-59. [CrossRef]

56. Di Ludovico, D.; Fabietti, V. Strategic Environmental Assessment, key issues of its effectiveness. The results of the Speedy Project. Environ. Impact Assess. Rev. 2018, 68, 19-28. [CrossRef]

57. Wang, Z.; Wu, F. In-Situ Marginalisation: Social Impact of Chinese Mega-Projects. Antipode 2019, 51, 1640-1663. [CrossRef]

58. Yang, W.; Liu, H.; Cui, W.; Yang, Z.; Wang, X. An Optimization and Selection Method for Planning Projects of MV Distribution Network Considering Categorization of Project Attributes. In Proceedings of the 6th International Conference on Energy and Environmental Protection (ICEEP 2017), Zhuhai, China, 29-30 June 2017.

59. Lehtinen, J.; Aaltonen, K. Organizing external stakeholder engagement in inter-organizational projects: Opening the black box. Int. J. Proj. Manag. 2020, 38, 85-98. [CrossRef]

60. Bryce, J.; Flintsch, G.; Hall, R.P. A multi criteria decision analysis technique for including environmental impacts in sustainable infrastructure management business practices. Transp. Res. Part D Transp. Environ. 2014, 32, 435-445. [CrossRef]

61. Ahern, A.; Anandarajah, G. Railway projects prioritisation for investment: Application of goal programming. Transp. Policy 2007, 14, 70-80. [CrossRef]

62. Qiu, M. Prioritising and scheduling road projects by genetic algorithm. Math. Comput. Simul. 1997, 43, 569-574. [CrossRef]

63. Aladag, H.; Isik, Z. The Effect of Stakeholder-Associated Risks in Mega-Engineering Projects: A Case Study of a PPP Airport Project. IEEE Trans. Eng. Manag. 2020, 67, 174-186. [CrossRef]

64. Öztayşi, B. A decision model for information technology selection using AHP integrated TOPSIS-Grey: The case of content management systems. Knowledge-Based Syst. 2014, 70, 44-54. [CrossRef]

65. Machado, T.C.S.; Pinheiro, P.R.; Tamanini, I. Project management aided by verbal decision analysis approaches: A case study for the selection of the best SCRUM practices. Int. Trans. Oper. Res. 2014, 22, 287-312. [CrossRef]

66. Jafarzadeh, M.; Tareghian, H.; Rahbarnia, F.; Ghanbari, R. Optimal selection of project portfolios using reinvestment strategy within a flexible time horizon. Eur. J. Oper. Res. 2015, 243, 658-664. [CrossRef]

67. Oztaysi, B. A Group Decision Making Approach Using Interval Type-2 Fuzzy AHP for Enterprise Information Systems Project Selection. J. Mult. Valued Logic Soft Comput. 2015, 24, 475-500.

68. Jafarzadeh, H.; Akbari, P.; Abedin, B. A methodology for project portfolio selection under criteria prioritisation, uncertainty and projects interdependency-combination of fuzzy QFD and DEA. Expert Syst. Appl. 2018, 110, 237-249. [CrossRef]

69. Pramanik, D.; Mondal, S.C.; Haldar, A. A framework for managing uncertainty in information system project selection: An intelligent fuzzy approach. Int. J. Manag. Sci. Eng. Manag. 2019, 15, 70-78. [CrossRef]

70. Kovach, J.; Ingle, D. An approach for identifying and selecting improvement projects. Total. Qual. Manag. Bus. Excel. 2018, 31, 1-12. [CrossRef]

71. Simplício, R.; Gomes, J.; Romão, M. Projects Selection and Prioritization: A Portuguese Navy pilot model. Procedia Comput. Sci. 2017, 121, 72-79. [CrossRef] 
72. Asrilhant, B.; Meadows, M.; Dyson, R. Techniques to Support Successful Strategic Project Management in the UK Upstream Oil and Gas Sector. Eur. Manag. J. 2006, 24, 214-225. [CrossRef]

73. Arlt, M. Advancing the Maturity of Project Portfolio Management through Methodology and Metrics Refinements. Ph.D. Thesis, RMIT University, Melbourne, Australia, 2010.

74. Ahmad, S.; Tahar, R.M. Selection of renewable energy sources for sustainable development of electricity generation system using analytic hierarchy process: A case of Malaysia. Renew. Energy 2014, 63, 458-466. [CrossRef]

75. Büyüközkan, G.; Güleryüz, S. An integrated DEMATEL-ANP approach for renewable energy resources selection in Turkey. Int. J. Prod. Econ. 2016, 182, 435-448. [CrossRef]

76. Ritter, M.; Deckert, L. Site assessment, turbine selection, and local feed-in tariffs through the wind energy index. Appl. Energy 2017, 185, 1087-1099. [CrossRef]

77. Saili, P.J.; Mwiya, B. Factors influencing project selection in the renewable energy sector of Zambia. Afr. J. Bus. Manag. 2018, 12, 674-682.

78. Ashuri, B.; Moradi, A.; Baek, M.; Kingsley, G.; An, H.Y.; Zhang, L.; Liang, Y.; Bahrami, S. Risk Mitigation Strategies to Enhance the Delivery of Highway Projects; No. FHWA-GA-18-1640; Georgia. Dept. of Transporation. Office of Performance-Based Management and Research: Atlanta, GA, USA, 2018.

79. Elbok, G.; Berrado, A. Categorizing Projects for Portfolio Selection Using Clustering Techniques; Association for Computing Machinery: Rabat, Morocco, 2018.

80. Dadashi, A.; Mirbaha, B. Prioritizing highway safety improvement projects: A Monte-Carlo based Data Envelopment Analysis approach. Accid. Anal. Prev. 2019, 123, 387-395. [CrossRef]

81. Dong, C.; Wang, H.; Chen, Q.; Ni, D.; Li, Y. Simulation-Based Assessment of Multilane Separate Freeways at Toll Station Area: A Case Study from Huludao Toll Station on Shenshan Freeway. Sustainability 2019, 11, 3057. [CrossRef]

82. Novak, D.; Koliba, C.; Zia, A.; Tucker, M. Evaluating the outcomes associated with an innovative change in a state-level transportation project prioritization process: A case study of Vermont. Transp. Policy 2015, 42, 130-143. [CrossRef]

83. Thamhain, H.J. Assessing the Effectiveness of Quantitative and Qualitative Methods for R\&D Project Proposal Evaluations. Eng. Manag. J. 2014, 26, 3-12. [CrossRef]

84. Rafiee, M.; Kianfar, F.; Farhadkhani, M. A multistage stochastic programming approach in project selection and scheduling. Int. J. Adv. Manuf. Technol. 2013, 70, 2125-2137. [CrossRef]

85. Tavana, M.; Keramatpour, M.; Santos-Arteaga, F.J.; Ghorbaniane, E. A fuzzy hybrid project portfolio selection method using Data Envelopment Analysis, TOPSIS and Integer Programming. Expert Syst. Appl. 2015, 42, 8432-8444. [CrossRef]

86. Mikkola, J.H. Portfolio management of R\&D projects: Implications for innovation management. Technovation 2001, 21, 423-435.

87. Hummel, J.M.; Oliveira, M.D.; Costa, C.A.B.e.; Jzerman, M.J.I. Supporting the Project Portfolio Selection Decision of Research and Development Investments by Means of Multi-Criteria Resource Allocation Modelling. In Multi-Criteria Decision Analysis to Support Healthcare Decisions; Marsh, K., Goetghebeur, M., Thokala, P., Baltussen, R., Eds.; Springer International Publishing: Berlin/Heidelberg, Germany, 2017; pp. 89-103.

88. Viljoen, P.J.; Steyn, H. A conceptual model for improved project selection and prioritisation. S. Afr. J. Ind. Eng. 2012, 18, 91-106. [CrossRef]

89. Nowak, M. Project Portfolio Selection Using Interactive Approach. Procedia Eng. 2013, 57, 814-822. [CrossRef]

90. Atal, V.; Bar, T.R.; Gordon, S. Project selection: Commitment and competition. Games Econ. Behav. 2016, 96, 30-48. [CrossRef]

91. Khalili-Damghani, K.; Tavana, M. A Comprehensive Framework for Sustainable Project Portfolio Selection Based on Structural Equation Modeling. Proj. Manag. J. 2014, 45, 83-97. [CrossRef]

92. Da Silva, C.G.; Meidanis, J.; Moura, A.V.; Souza, M.A.; Viadanna, P.; De Oliveira, M.R.; De Oliveira, M.R.; Jardim, L.H.; Lima, G.A.C.; De Barros, R.S. An improved visualization-based approach for project portfolio selection. Comput. Hum. Behav. 2017, 73, 685-696. [CrossRef]

93. Carvalho, M.; Patah, L.A.; Bido, D.D.S. Project management and its effects on project success: Cross-country and cross-industry comparisons. Int. J. Proj. Manag. 2015, 33, 1509-1522. [CrossRef] 
94. Ding, Z.; Sun, S.L.; Au, K. Angel investors' selection criteria: A comparative institutional perspective. Asia Pac. J. Manag. 2014, 31, 705-731. [CrossRef]

95. Esfahani, H.N.; Sobhiyah, M.H.; Yousefi, V.R. Project Portfolio Selection via Harmony Search Algorithm and Modern Portfolio Theory. Procedia - Soc. Behav. Sci. 2016, 226, 51-58. [CrossRef]

96. Ghasemzadeh, F.; Archer, N. Project portfolio selection through decision support. Decis. Support Syst. 2000, 29, 73-88. [CrossRef]

97. Ishizaka, A.; Siraj, S. Are multi-criteria decision-making tools useful? An experimental comparative study of three methods. Eur. J. Oper. Res. 2018, 264, 462-471. [CrossRef]

98. Cooper, R.G.; Edgett, S.J.; Kleinschmidt, E.J. Portfolio Management in New Product Development: Lessons from the Leaders-II. Res. Manag. 1997, 40, 43-52. [CrossRef]

99. Crossan, M.M.; Apaydin, M. A Multi-Dimensional Framework of Organizational Innovation: A Systematic Review of the Literature. J. Manag. Stud. 2009, 47, 1154-1191. [CrossRef]

100. Ceria, S.; Saxena, A.; Stubbs, R.A. Factor Alignment Problems and Quantitative Portfolio Management. J. Portf. Manag. 2012, 38, 29-43. [CrossRef]

101. Hutzschenreuter, T.; Horstkotte, J. Performance effects of top management team demographic faultlines in the process of product diversification. Strat. Manag. J. 2012, 34, 704-726. [CrossRef]

102. Chemweno, P.; Pintelon, L.; Van Horenbeek, A.; Muchiri, P. Development of a risk assessment selection methodology for asset maintenance decision making: An analytic network process (ANP) approach. Int. J. Prod. Econ. 2015, 170, 663-676. [CrossRef]

103. Hall, N.G.; Long, D.Z.; Qi, J.; Sim, M. Managing Underperformance Risk in Project Portfolio Selection. Oper. Res. 2015, 63, 660-675. [CrossRef]

104. Ouenniche, J.; Boukouras, A.; Rajabi, M. An Ordinal Game Theory Approach to the Analysis and Selection of Partners in Public-Private Partnership Projects. J. Optim. Theory Appl. 2015, 169, 314-343. [CrossRef]

105. Nyborg, K. Project evaluation with democratic decision-making: What does cost-benefit analysis really measure? Ecol. Econ. 2014, 106, 124-131. [CrossRef]

106. Maghsoodi, A.I.; Kavian, A.; Khalilzadeh, M.; Brauers, W.K. CLUS-MCDA: A novel framework based on cluster analysis and multiple criteria decision theory in a supplier selection problem. Comput. Ind. Eng. 2018, 118, 409-422. [CrossRef]

107. King, A.L.; Martini, P.; Davis, T.M.; Denney, K.D.; Kochanek, C.S.; Peterson, B.M.; Skielboe, A.; Vestergaard, M.; Huff, E.; Watson, D.; et al. Simulations of the OzDES AGN reverberation mapping project. Mon. Not. R. Astron. Soc. 2015, 453, 1701-1726. [CrossRef]

108. Adler, P.S.; Mandelbaum, A.; Nguyen, V.; Schwerer, E. Getting the most out of your product development process. Harv. Bus. Rev. 1996, 74, 134.

109. Meskendahl, S. The influence of business strategy on project portfolio management and its success-A conceptual framework. Int. J. Proj. Manag. 2010, 28, 807-817. [CrossRef]

110. Benko, C.; Mcfarlan, F.W. Connecting the Dots: Aligning Projects with Objectives in Unpredictable Times; Harvard Business Press: Brighton, MA, USA, 2003.

111. Association for Project Management. Directing Change: A Guide to Governance of Project Management; Association for Project Management: High Wycombe, UK, 2011.

112. Padalkar, M.; Gopinath, S. Six decades of project management research: Thematic trends and future opportunities. Int. J. Proj. Manag. 2016, 34, 1305-1321. [CrossRef]

113. Forcael, E.; Morales, H.; Agdas, D.; Rodríguez, C.; León, C. Risk Identification in the Chilean Tunneling Industry. Eng. Manag. J. 2018, 30, 203-215. [CrossRef]

114. Meulbroek, L.K. Integrated Risk Management for the Firm: A Senior Manager's Guide. SSRN Electron. J. 2002, 301331. [CrossRef]

115. Demirkesen, S.; Ozorhon, B. Measuring Project Management Performance: Case of Construction Industry. Eng. Manag. J. 2017, 29, 258-277. [CrossRef]

116. Miller, K.D.; Waller, H. Scenarios, Real Options and Integrated Risk Management. Long Range Plan. 2003, 36, 93-107. [CrossRef]

117. D'arcy, S.P.; Brogan, J.C. Enterprise risk management. J. Risk Manag. Korea 2001, 12, 207-228.

118. Sirisomboonsuk, P.; Gu, V.C.; Cao, R.Q.; Burns, J.R. Relationships between project governance and information technology governance and their impact on project performance. Int. J. Proj. Manag. 2018, 36, 287-300. [CrossRef] 
119. Musawir, A.U.; Serra, C.E.M.; Zwikael, O.; Ali, I. Project governance, benefit management, and project success: Towards a framework for supporting organizational strategy implementation. Int. J. Proj. Manag. 2017, 35, 1658-1672. [CrossRef]

120. Koh, A.; Crawford, L. Portfolio Management: The Australian Experience. Proj. Manag. J. 2012, 43, $33-42$. [CrossRef]

121. Jiang, A.; Malek, M.; Elsafty, A. Business Strategy and Capital Allocation Optimization Model for Practitioners. J. Manag. Eng. 2011, 27, 58-63. [CrossRef]

122. Killen, C.P.; Jugdev, K.; Drouin, N.; Petit, Y. Advancing project and portfolio management research: Applying strategic management theories. Int. J. Proj. Manag. 2012, 28, 525-553. [CrossRef]

123. Elonen, S.; Artto, K.A. Problems in managing internal development projects in multi-project environments. Int. J. Proj. Manag. 2003, 21, 395-402. [CrossRef]

124. Pinto, J.K. Project management, governance, and the normalization of deviance. Int. J. Proj. Manag. 2014, 32, 376-387. [CrossRef]

125. Crawford, L.H.; Helm, J. Government and Governance: The Value of Project Management in the Public Sector. Proj. Manag. J. 2009, 40, 73-87. [CrossRef]

126. Bekker, M.C.; Styen, H. Defining 'project governance' for large capital projects. S. Afr. J. Ind. Eng. 2007, 20, 81-92. [CrossRef]

127. Zwikael, O.; Smyrk, J. A General Framework for Gauging the Performance of Initiatives to Enhance Organizational Value. Br. J. Manag. 2012, 23, S6-S22. [CrossRef]

128. Samset, K.; Volden, G.H. Front-end definition of projects: Ten paradoxes and some reflections regarding project management and project governance. Int. J. Proj. Manag. 2016, 34, 297-313. [CrossRef]

129. Liu, L.; Yetton, P. The contingent effects of project governance mechanisms on project delivery capability and the level of control-evidence from the construction and IT services industries. In Proceedings of the Pan-Pacific Business Conference, Shanghai, China, 14 July 2004.

130. Too, E.; Weaver, P. The management of project management: A conceptual framework for project governance. Int. J. Proj. Manag. 2014, 32, 1382-1394. [CrossRef]

131. Haq, S.U.; Liang, C.; Gu, D.; Du, J.T.; Zhao, S. Project Governance, Project Performance, and the Mediating Role of Project Quality and Project Management Risk: An Agency Theory Perspective. Eng. Manag. J. 2018, 30, 274-292. [CrossRef]

132. Nanthagopan, Y.; Williams, N.; Page, S.J. Understanding the nature of Project Management capacity in Sri Lankan non-governmental organisations (NGOs): A Resource Based Perspective. Int. J. Proj. Manag. 2016, 34, 1608-1624. [CrossRef]

133. Schiffels, S.; Fliedner, T.; Kolisch, R. Human Behavior in Project Portfolio Selection: Insights from an Experimental Study. Decis. Sci. 2018, 49, 1061-1087. [CrossRef]

134. Martens, M.L.; Carvalho, M. The challenge of introducing sustainability into project management function: Multiple-case studies. J. Clean. Prod. 2016, 117, 29-40. [CrossRef]

135. Belassi, W.; Kondra, A.Z.; Tukel, O.I. New Product Development Projects: The Effects of Organizational Culture. Proj. Manag. J. 2007, 38, 12-24. [CrossRef]

136. Heckmann, N.; Steger, T.; Dowling, M. Organizational capacity for change, change experience, and change project performance. J. Bus. Res. 2016, 69, 777-784. [CrossRef]

137. Ketkar, H.; Workiewicz, M. Project Screening and Resource Allocation in Boss-less Organizations. Acad. Manag. Proc. 2017, 2017, 17638. [CrossRef]

138. Markou, C.; Koulinas, G.K.; Vavatsikos, A.P. Project resources scheduling and leveling using Multi-Attribute Decision Models: Models implementation and case study. Expert Syst. Appl. 2017, 77, 160-169. [CrossRef]

139. Naldi, M.; Nicosia, G.; Pacifici, A.; Pferschy, U. Maximin Fairness in Project Budget Allocation. Electron. Notes Discret. Math. 2016, 55, 65-68. [CrossRef]

140. Karlsen, J.T. Project Stakeholder Management. Eng. Manag. J. 2002, 14, 19-24. [CrossRef]

141. Yalegama, S.; Chileshe, N.; Ma, T. Critical success factors for community-driven development projects: A Sri Lankan community perspective. Int. J. Proj. Manag. 2016, 34, 643-659. [CrossRef]

142. Turner, J.R. The management of the project-based organization: A personal reflection. Int. J. Proj. Manag. 2018, 36, 231-240. [CrossRef]

143. Eskerod, P.; Huemann, M.; Ringhofer, C. Stakeholder Inclusiveness: Enriching Project Management with General Stakeholder Theory. Proj. Manag. J. 2015, 46, 42-53. [CrossRef] 
144. Zwikael, O.; Meredith, J. Evaluating the Success of a Project and the Performance of Its Leaders. IEEE Trans. Eng. Manag. 2019, 1-13. [CrossRef]

145. Meredih, J.; Zwikael, O. When is a Project Successful? IEEE Eng. Manag. Rev. 2019, 47, 127-134. [CrossRef]

146. Ibbs, W.; Reginato, J. Quantifying the Value of Project Management: Best Practices for Improving Project Management Processes, Systems, and Competencies; Project Management Institute: Philadelphia, PA, USA, 2002.

147. Shenhar, A.J.; Dvir, D. How Projects Differ and What to Do about It. In The Wiley Guide to Project, Program and Portfolio Management; John Wiley and Sons Inc.: Hoboken, NJ, USA, 2007; pp. 177-198.

148. Dyett, V. Roles and Characteristics of the Project Manager in Achieving Success across the Project Life Cycle. Publication number AAT:3455628. Ph.D. Thesis, Lynn University, Boca Raton, FL, USA, 2011.

149. Kwak, Y.H.; Sadatsafavi, H.; Walewski, J.; Williams, N.L. Evolution of project based organization: A case study. Int. J. Proj. Manag. 2015, 33, 1652-1664. [CrossRef]

150. Zhai, L.; Xin, Y.; Cheng, C. Understanding the value of project management from a stakeholder's perspective: Case study of mega project management. Proj. Manag. J. 2009, 40, 99-109. [CrossRef]

151. Martinsuo, M. The Management of Values in Project Business: Adjusting Beliefs to Transform Project Practices and Outcomes. Proj. Manag. J. 2020, 389-399. [CrossRef]

152. Maniak, R.; Midler, C.; Lenfle, S.; Le Pellec-Dairon, M. Value Management for Exploration Projects. Proj. Manag. J. 2014, 45, 55-66. [CrossRef]

153. Pokharel, S.; Chandrashekar, M. A multiobjective approach to rural energy policy analysis. Energy 1998, 23, 325-336. [CrossRef]

(C) 2020 by the authors. Licensee MDPI, Basel, Switzerland. This article is an open access article distributed under the terms and conditions of the Creative Commons Attribution (CC BY) license (http://creativecommons.org/licenses/by/4.0/). 